\title{
Glycogen Synthase Kinase-3 Regulation of Chromatin Segregation and Cytokinesis in Mouse Preimplantation Embryos
}

\author{
NICOLE ACEVEDO,${ }^{1,4}$ XIA WANG,${ }^{3,4}$ RODNEY L. DUNN, ${ }^{2}$ AND GARY D. SMITH ${ }^{1,2,3,4 *}$ \\ ${ }^{1}$ Departments of Molecular and Integrative Physiology, University of Michigan, Ann Arbor, Michigan \\ ${ }^{2}$ Department of Urology, University of Michigan, Ann Arbor, Michigan \\ ${ }^{3}$ Departments of Obstetrics and Gynecology, University of Michigan, Ann Arbor, Michigan \\ ${ }^{4}$ Department of Reproductive Sciences Program, University of Michigan, Ann Arbor, Michigan
}

ABSTRACT Glycogen synthase kinase-3 (GSK-3) is a highly conserved serine/threonine protein kinase implicated in diverse cellular processes. Activity of GSK-3 is essential for meiotic chromatin segregation in oocytes, yet expression and/or function of GSK-3 have not been reported in mammalian preimplantation embryos. Objectives of this study were to characterize GSK-3 protein expression/phosphorylation in mouse preimplantation embryos, to assess the effect of GSK-3 activity inhibition on early mitotic events, and to differentiate nuclear and cytoplasmic anomalies in GSK-3 inhibited embryos. Both GSK-3 isoforms were expressed during embryo development, with a differential expression of $\alpha$ versus $\beta$. Phosphorylation of GSK-3 $\alpha / \beta$ at residues $Y 279 / Y 216$ indicated constitutive activation throughout preimplantation development. Phosphorylation at N-terminal residues S21/S9 indicated inhibition of GSK-3 $\alpha / \beta$ activity that was differentially regulated during early development; both $\alpha$ and $\beta$ isoforms were phosphorylated during early divisions, whereas at the blastocyst stage, only $\beta$ was phosphorylated. Cytoplasmic microinjection of zygotes with anti-GSK-3 $\alpha / \beta$ antibody significantly compromised embryonic development past the two-cell stage compared to controls. Reversibility of developmental block was tested via pharmacological inhibitors of GSK-3, lithium chloride ( $\mathrm{LiCl}$ ) and alsterpaullone. Similar to immunoneutralization, significantly fewer zygotes cultured with either $\mathrm{LiCl}$ or alsterpaullone developed past the two-cell stage compared to controls and this mitotic block was not reversible. Inhibition of GSK-3 activity significantly compromised timing of pronuclear membrane breakdown and mitosis initiation, nuclear development, and cytokinesis. Inhibition of GSK-3 also resulted in abnormal chromatin segregation, evidenced by incomplete karyokinesis and micronuclei formation. These results suggest that GSK-3 activity is critical for early preimplantation embryonic development. Mol. Reprod. Dev. 74: 178-188, 2007. (c) 2006 Wiley-Liss, Inc.

Key Words: chromatin segregation; cytokinesis; embryo; glycogen synthase kinase-3

\section{INTRODUCTION}

Oocyte meiotic and embryo mitotic competence are directly associated with proper spindle function and chromosome segregation (Generoso et al., 1989; Battaglia et al., 1996; Sun et al., 2005). The first mitotic M phase is characterized by alignment of condensed chromatin on a metaphase plate, separation of sister chromatids by a microtubular spindle apparatus, and microfilament-mediated cleavage of zygotic cytoplasm into two cells termed cytokinesis (Kaufman, 1973; Inoue, 1981; Ciemerych and Czolowska, 1993; Collas et al., 1999). Each cell, or blastomere, in two-cell embryos contains a complete complement of chromosomes. Disruption of microtubule function during oocyte maturation or fertilization leads to aberrations in embryo chromosomal ploidy (Generoso et al., 1989; Yu et al., 2002; Sun et al., 2005). Although oocyte-derived mRNA and protein products contribute to the first few embryonic divisions, mouse embryos undergoes major zygotic genomic activation (ZGA), during the two-cell stage, to sustain early preimplantation development (Haraguchi et al., 1998).

Major intracellular events mediating first embryonic divisions are not clearly understood. Nevertheless, it is known that cell cycle progression is regulated by reversible protein phosphorylation. Earlier studies indicated that transient changes in $c$-mos proto-oncogene product (Mos), mitogen-activated protein (MAP) kinases ERK1/2, and M-phase promoting factor (MPF) activities occur during the first cell cycle, independent of nuclear or exogenous mitogenic control (Masui and Markert, 1971; Ciemerych, 1995; Winston and Maro,

Grant sponsor: Experiments contained in this manuscript were supported by NIH grant HD35125 (G.D.S.). Support for N.A. was provided by NIH Training Grants in Systems and Integrative Biology T32-GM08322 (John Williams) and in Reproductive Sciences T32HD07048 (Douglas Foster).

*Correspondence to: Gary D. Smith, 6428 Medical Sciences I, 1301 E. Catherine St, Ann Arbor, MI 48109-0617. E-mail: smithgd@umich.edu

Received 23 November 2005; Accepted 17 January 2006

Published online 29 August 2006 in Wiley InterScience (www.interscience.wiley.com).

DOI $10.1002 / \operatorname{mrd} .20495$ 
1995). Transition from a meiotic to mitotic cell cycle in fertilized mammalian oocytes requires transient inactivation of MPF and Mos, that in turn mediate activation of MAP kinases (Verlhac et al., 1993, 1996; Gebauer and Richter, 1997; Josefsberg et al., 2003). In somatic cells, activation of MAP kinases, ERK1 and 2, is required for initiation of mitosis, nuclear translocation of cyclin B1, timely progression from metaphase to anaphase, and regulation of spindle assembly (Robinson and Cobb, 1997; Guadagno and Ferrell, 1998; Roberts et al., 2002; Horne and Guadagno, 2003; Liu et al., 2004). Activation of ERK1/2 occurs during meiotic maturation in mouse oocytes (Verlhac et al., 1996; Lu et al., 2002). However, high MAP kinase activity in the absence of ERK activation in early mouse embryo suggests that an additional MAP kinase signaling cascade may exist at this stage of development (Haraguchi et al., 1998). Additionally, the phosphotidylinositol-3-kinase (PI3K) pathway facilitates cell cycle progression at onset of mitosis and is required for completion of the mammalian cell cycle via regulation of protein kinase $B(\mathrm{PKB})$. Despite importance of the PI3K pathway, downstream effectors in this pathway are not well characterized (Roberts et al., 2002; Alvarez et al., 2003). More recently, Polo and Aurora kinases were found to regulate mitotic spindle function through microtubule-dependent and independent mechanisms (Doxsey, 2001; Hannak et al., 2001; do Carmo Avides et al., 2001; Delaval et al., 2004). These studies suggest that the full array of kinases that control early mitotic events has not been elucidated, thus validating further investigation of potential regulators.

Glycogen synthase kinase-3 (GSK-3) is a serine/ threonine protein kinase that consists of two isoforms, $\alpha$ and $\beta$, and regulation of GSK-3 activity occurs via reversible phosphorylation. Constitutive phosphorylation of its tyrosine (Y279 of $\alpha / \mathrm{Y} 216$ of $\beta$ ) residues leads to GSK-3 activation, whereas regulated phosphorylation of its serine (S21 of $\alpha / \mathrm{S} 9$ of $\beta$ ) residues results in inactivation (Embi et al., 1980; Welsh and Proud, 1993). Cellular processes that utilize GSK-3 include glycogen metabolism, specification of cell fates during post-implantation embryo development, control of cell division, microtubule dynamics and chromosomal alignment, and apoptosis (Embi et al., 1980; Klein and Melton, 1996; Cohen and Frame, 2001; Loberg et al., 2002; Cho and Johnson, 2003; Wakefield et al., 2003; Wang et al., 2003). GSK-3 has been shown to play a major role in early morphogenesis of invertebrate and vertebrate embryos, including Xenopus (Dominguez et al., 1995; Pierce and Kimelman, 1995; Klein and Melton, 1996), sea urchins (Davidson et al., 1998), zebrafish (Sumoy et al., 1999), and mice (Ossipova et al., 2003). However, the role of GSK-3 in regulation of mammalian oocyte and preimplantation embryo development is not well understood.

Several studies have implicated GSK-3 in regulation of microtubule dynamics during mitosis. Glycogen synthase kinsase-3 appears necessary for development of a competent spindle apparatus and thus successful chromosomal segregation (Lovestone et al., 1996; Doxsey, 2001; Wakefield et al., 2003). In neuronal cells, changes in microtubule dynamics observed during mitosis occur concurrently with phosphorylation of several microtubule-associated proteins (MAPs), including tau (Lovestone et al., 1996, 1999; Sang et al., 2001; Wakefield et al., 2003). Active GSK-3 has been shown to phosphorylate these MAPs (Woodgett, 1990). While MAPs have been best characterized in neurons, it is unknown if they regulate microtubular spindle dynamics in oocytes or embryos. In HeLa cells, GSK-3 is phosphorylated along the spindle apparatus in a temporal and spatial manner during mitosis, and inhibition of GSK-3 activity promotes mitotic spindle defects, impairs chromosomal movement, and induces improper chromosomal alignment/segregation (Wakefield et al., 2003). Recently, GSK-3 activity was shown to be essential for normal oocyte meiotic chromatin segregation, but the mechanism of GSK-3-mediated homologue segregation has not been investigated (Wang et al., 2003). Collectively, these reports support the hypothesis of GSK-3 regulating meiotic and mitotic chromatin segregation.

Lithium chloride ( $\mathrm{LiCl}$ ) inhibition of GSK-3 activity in living cell cultures has been well characterized in various systems, including Xenopus and sea urchin oocytes and embryos (Klein and Melton, 1996; Hedgepeth et al., 1997, 1999a,b; Emily-Fenouil et al., 1998; Vonica et al., 2000). Lithium potently inhibits GSK-3, however, its specificity for GSK-3 has been questioned because of its ability to inhibit alternative targets, including inositol monophosphatase [IMPase] (Berridge et al., 1989; Stambolic et al., 1996). Paullones, particularly alsterpaullone, potently and selectively inhibit GSK-3 and cyclin-dependent kinases (CDKs) 1/2/5 activity in cell-free extracts, but display a greater selectivity for inhibiting GSK-3 in cell culture (Leost et al., 2000; Tatebayashi et al., 2004). Lithium, on the other hand, has not been shown to regulate the inhibition of any known CDK (Klein and Melton, 1996; Davies et al., 2000; Phiel and Klein, 2001). Comparison of the effects of paullones and $\mathrm{LiCl}$ on inhibition of protein kinases in cell-free extracts suggests that the combined use of these compounds may help identify both physiological substrates and roles of GSK-3 (Davies et al., 2000; Bain et al., 2003). For these reasons, a combinatorial approach of lithium and alsterpaullone pharmacological inhibition may serve as a powerful tool for understanding roles of GSK-3 regulation in early preimplantation embryos.

At present, there are no reports on presence or function of GSK- $3 \alpha$ or $\beta$ in mammalian preimplantion embryos. Objectives of this study were to characterize GSK- $3 \alpha$ and $\beta$ expression/phosphorylation in preimplantation embryos, assess effects of GSK-3 inhibition on early mitotic events, and differentiate nuclear and cytoplasmic anomalies in GSK-3 inhibited embryos. Our results indicate that in mammalian embryos, GSK-3 activity regulates mitotic cell cycle progression and is critical for normal chromatin segregation and cytokinesis. 


\section{N. ACEVEDO ET AL.}

\section{MATERIALS AND METHODS \\ Collection of Oocytes and Preimplantation Mouse Embryos}

Animals used in these experiments were treated in accordance with approved protocols by the Animal Care and Use Committee of the University of Michigan. Chemicals were purchased from Sigma Chemical Co. (St. Louis, MO), unless otherwise indicated. To isolate mature oocytes, oviducts were collected from 6 to 8 weeks old CF-1 mice stimulated with $10 \mathrm{IU}$ each of equine chorionic gonadotropin (eCG) and human chorionic gonadotropin (hCG) administered $48 \mathrm{hr}$ apart. In vivomatured metaphase II (MII) oocytes were isolated into HEPES buffered Human Tubal Fluid media (HTFH; Irvine Scientific, Santa Ana, CA) + 0.3\% (wt/vol) polyvinylpyrrolidine (PVP) then frozen in liquid nitrogen and stored at $-80^{\circ} \mathrm{C}$ until protein extracts were prepared. To isolate one-cell embryos (zygotes), oviducts were collected from 6 to 8 weeks old CF-1 mice stimulated with 10 IU each of eCG and hCG administered $48 \mathrm{hr}$ apart, then mated with CF-1 males. Cumulus-enclosed zygotes were isolated into HEPES buffered KSOM media (H-KSOM; as described previously (Lawitts and Biggers, 1993) $+0.3 \%$ (wt/vol) bovine serum albumin (BSA; Fisher Scientific, Pittsburgh, PA) and cumulus cells removed with hyaluronidase. Zygotes were cultured in KSOM media with 1/2 amino acids and glucose (Specialty Media, Phillipsburg, $\mathrm{NJ})+3 \%$ (wt/vol) BSA for up to $96 \mathrm{hr}$. For Western blot analyses, cumulus-free zygotes, two-cell, four-cell, and blastocyst-stage embryos were washed in H-KSOM + $0.3 \%$ (wt/vol) PVP, then frozen in liquid nitrogen and stored at $-80^{\circ} \mathrm{C}$ until protein extracts were prepared. For culture experiments, zygotes were placed either in $\mathrm{KSOM}+3 \%$ BSA (KSOM alone) or containing potassium chloride (KCl; Fisher Scientific), LiCl, alsterpaullone (Calbiochem, San Diego, CA), or L-690, 330 (Tocris, Ballwin, MO).

\section{Electrophoresis and Western Blot Analysis}

Frozen cumulus cell-free MII oocytes, zygotes, twocell, four-cell, and blastocyst stage embryos were thawed in 2X SDS-PAGE sample buffer [80 mM TrisHCL (pH 6.8), 20\% (vol/vol) glycerol, 4\% (wt/vol) SDS, $4 \%$ (vol/vol) 2-mercaptoethanol, and $0.04 \%$ (wt/vol) bromophenol blue], vortexed, and placed on ice for 15 min. Following sonication on ice for $10 \mathrm{sec}$, samples were denatured at $90^{\circ} \mathrm{C}$ for $10 \mathrm{~min}$ and cooled on ice for $5 \mathrm{~min}$. One microgram of mouse brain and entire cell lysates of embryos $(\mathrm{N}=80-200)$ were added per lane and separated by one-dimensional SDS-PAGE as described previously (Wang et al., 2003). Blots were either probed with anti-GSK- $3 \alpha / \beta$ (Upstate Biotechnology, Charlottesville, VA), anti-phosphotyrosine-GSK-3 $\alpha / \beta$ (Y279/216; Upstate Biotechnology), or anti-phosphoserine-GSK-3 $\alpha / \beta$ (Ser 21/9; Cell Signaling Technology, Beverly, MA). Blots were performed in duplicate and visualized with ECL Plus chemiluminescence reagents
(Amersham Life Sciences, Buckinghamshire, UK). Isoform protein levels were compared within developmental stages via densitometry analysis.

\section{Immunocytochemistry}

Zygotes were isolated and cultured in KSOM $+3 \%$ BSA to identify localization of GSK-3 during the first mitotic metaphase. At $35 \mathrm{hr}$ post-hCG administration, embryos were fixed and permeabilized in 2\% (wt/vol) paraformaldehyde with $0.5 \%$ (vol/vol) Triton-X-100 for $45 \mathrm{~min}$ at $37^{\circ} \mathrm{C}$. Embryos were washed three times then blocked overnight at $4{ }^{\circ} \mathrm{C}$ with a solution of $\mathrm{PBS}$ containing $2 \%$ BSA, $2 \%$ powdered milk, $0.1 \mathrm{M}$ glycine, and $0.5 \%$ Triton-X-100. Primary antibody incubations were carried out for $1 \mathrm{hr}$ at $37^{\circ}$ in humidified chambers. The following primary antibodies were used: anti-GSK$3 \alpha / \beta$ (1:100; Upstate Biotechnology), anti-GSK-3 $\alpha$ (1:50; Abgent, San Diego, CA), and $\beta$-tubulin (1:200; Sigma). Nonimmune mouse and rabbit serum (NIMS and NIRS, respectively) were substituted for primary antibodies as negative controls. Staining was visualized using the following secondary antibodies: anti-mouse Alexa Fluor $^{\circledR}$ 568, anti-rabbit Alexa Fluor ${ }^{\circledR} 568$, and antimouse Alexa Fluor ${ }^{\circledR} 488$ (all 1:750; Molecular Probes, Eugene, OR). Chromatin was counterstained with mounting solution containing Hoescht 33342 (Sigma).

\section{Antibody Microinjection}

Zygotes were collected as described above and placed into $\mathrm{HTFH}+\mathrm{PVP}$ medium, then microinjected on a Nikon inverted microscope with Hoffman optics equipped with Narishige micromanipulators and a Brinkmann Eppendorf microinjector (Brinkmann Eppendorf, Westbury, NY). Zygotes were cytoplasmically microinjected at $400 \times$ magnification with $\sim 6 \mathrm{pl}$ of undiluted anti-GSK-3 $\alpha / \beta$ (Upstate Biotechnology, Lake Placid, NY). Microinjected volumes were confirmed as previously described (Corson and Fein, 1983). Controls for the antibody microinjection included injection of mouse serum IgG, phosphate buffered saline ( $\mathrm{PBS}, \mathrm{pH}=7.4$; vehicle control for mouse IgG), or antibody diluent [0.1 M Tris-glycine ( $\mathrm{pH} 7.4$ ), $0.15 \mathrm{M} \mathrm{NaCl}, 0.05 \%$ sodium azide; vehicle control for antibody]. Following microinjection, embryos were cultured for $48 \mathrm{hr}$ in $50 \mu \mathrm{l}$ microdrops of KSOM media overlayed with mineral oil. Embryos were microscopically assessed at 24-hr intervals for cleavage events.

\section{Pharmacological Inhibition of GSK-3 and Morphological Analyses}

Zygotes were collected as described above and cultured for $72 \mathrm{hr}$ in KSOM alone or containing 1, 10, or $20 \mathrm{mM} \mathrm{LiCl}$ to determine if continual $\mathrm{LiCl}$ exposure influenced embryo development in a dose-dependent manner. To ascertain that repression of development by $\mathrm{LiCl}$ was due to GSK-3 and not IMPase inhibition, zygotes were cultured for $72 \mathrm{hr}$ in KSOM alone or containing $20 \mathrm{mM} \mathrm{LiCl}, 20 \mathrm{mM} \mathrm{KCl}$ (molarity control), or 
$20 \mu \mathrm{M}$ L-690, 330 (specific IMPase inhibitor). Zygotes were cultured for $30 \mathrm{hr}$ in $\mathrm{KSOM}$ alone, $20 \mathrm{mM} \mathrm{LiCl}$, or $20 \mathrm{mM} \mathrm{KCl}$, then washed and transferred to KSOM alone for up to $48 \mathrm{hr}$ total culture to assess if embryos could regain mitotic potential after removal from GSK-3 inhibition. To verify that block of development at twocell stage was due to selective inhibition of GSK-3 not CDK activity, zygotes were cultured for $96 \mathrm{hr}$ in KSOM alone, $20 \mathrm{mM} \mathrm{LiCl,} 20 \mu \mathrm{M}$ alsterpaullone, or $80 \mu \mathrm{M}$ roscovitine (selective CDK 1/2/5 inhibitor). Zygotes were individually cultured in $50 \mu \mathrm{l}$ microdrops for $24 \mathrm{hr}$ in KSOM alone or containing $20 \mathrm{mM} \mathrm{LiCl}, 20 \mathrm{mM} \mathrm{KCL}$, or $20 \mu \mathrm{M}$ alsterpaullone then examined at $3 \mathrm{hr}$ intervals using a Leica DMIRB inverted microscope with Hoffman modulation contrast optics $(40 \times)$ to assess nuclear and cytoplasmic events during the first mitotic division. After $24 \mathrm{hr}$ of culture, embryos were fixed and stained with Hoescht 33342 to visualize chromatin. Images were captured and processed with SPOT ${ }^{\mathrm{TM}}$ RT Slider digital camera and software (Diagnostic Instruments, Sterling Heights, MI).

\section{Statistical Analyses}

Each developmental study was performed in duplicate (Western blot analyses) or triplicate (morphological analyses), and cumulative results were analyzed using Chi-square $\left(\chi^{2}\right)$ analysis. Differences were considered significant at of $P<0.01$.

\section{RESULTS \\ GSK-3 is Expressed During Early Preimplantation Embryo Development and Co-Localizes With First Mitotic Spindle}

Activity of GSK-3 may be required for proper progression of fertilized oocytes through the first mitotic cleavage events. Western blot analysis was performed to determine presence/absence of GSK-3 protein in denuded mature oocytes and preimplantation embryos. Isoforms of GSK-3 $\alpha$ and $\beta$ (51 and $47 \mathrm{kDa}$, respectively) were identified in mouse MII oocytes, and in one-cell, two-cell, four-cell, and blastocyst-stage embryos. Additionally, there was differential expression of $\alpha$ and $\beta$ isoforms during preimplantation embryonic development (Fig. 1A). Specifically, densitometry analysis of $\alpha$ and $\beta$ isoforms showed a $2: 1(\alpha: \beta)$ expression ratio in MII oocytes and zygotes through four-cell embryos, whereas expression of GSK-3 in blastocysts and mouse brain (positive control tissue) was equivalent for each isoform. Both GSK-3 $\alpha$ and $\beta$ were phosphorylated at tyrosine residues throughout preimplantation embryo development, suggesting a basal state of constitutively active GSK-3 (Fig. 1B). With respect to GSK-3 inactivation, which involves $\mathrm{N}$-terminal serine phosphorylation, there appeared to be greater phosphorylation of S9 (GSK-3 $\beta$ ) than S21 (GSK-3 $\alpha$ ) residues throughout oocyte maturation and early embryonic divisions. However, by the blastocyst stage, only GSK-3 $\beta$ (and not GSK-3 $\alpha$ ) was
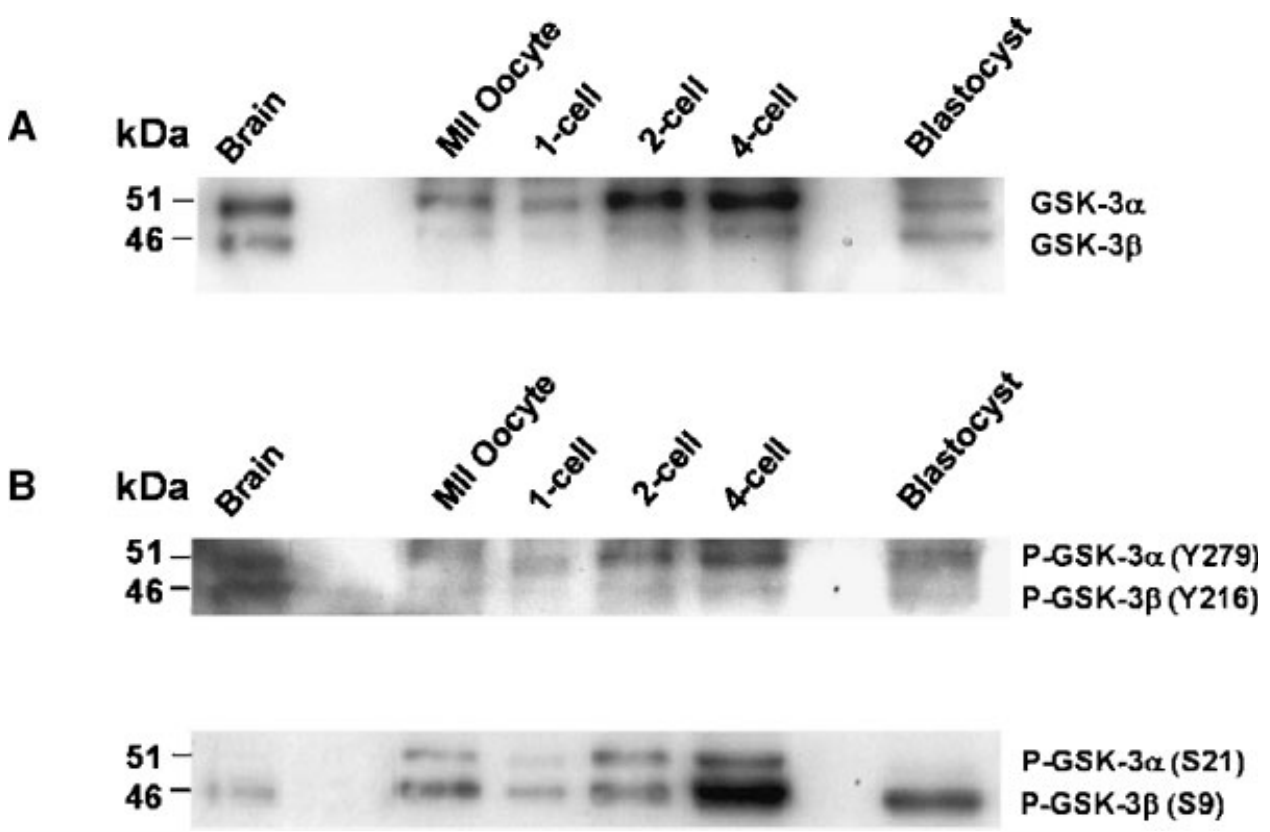

Fig. 1. Glycogen synthase kinase-3 (GSK-3) $\alpha$ and $\beta$ expression and phosphorylation during early preimplantation embryo development. Immunoblot analysis of GSK- $3 \alpha$ and $\beta$ in mature (MII) oocytes, and in early cleavage stage embryos. Mouse brain total protein $(1 \mu \mathrm{g})$ was used as positive control for GSK-3 $\alpha$ and $\beta$ expression. Total protein from MII oocytes, one-cell, two-cell, four-cell, and blastocyst embryo lysates (80200 embryos) were loaded per lane. A: Preimplantation embryos contained both GSK-3 $\alpha$ and $\beta$, but there was a differential expression of
GSK-3 $\alpha$ to $\beta$ isoforms in early preimplantation embryos compared to blastocyst embryos and mouse brain control. Western blots were probed with an antibody that recognized both $\alpha$ and $\beta$ isoforms. B: GSK-3 phosphorylation at a tyrosine residue (Y279 of $\alpha / \mathrm{Y} 216$ of $\beta$ ) indicates constitutive activation, whereas phosphorylation at an $\mathrm{N}$-terminal serine residue (S21 of $\alpha / \mathrm{S} 9$ of $\beta$ ) indicates regulated inhibition. Blots were probed with antibodies against phospho-GSK-3 $\alpha / \beta(Y 279 / 216)$ and phospho-GSK-3 $\alpha / \beta$ (S21/S9), respectively. 
A
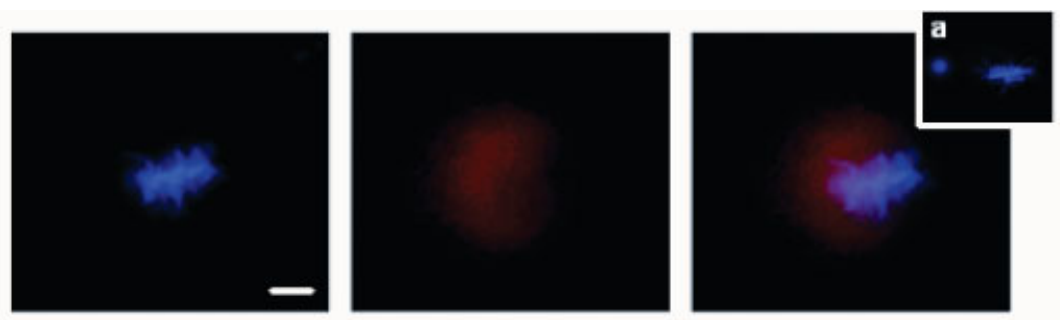

B

Prometaphase
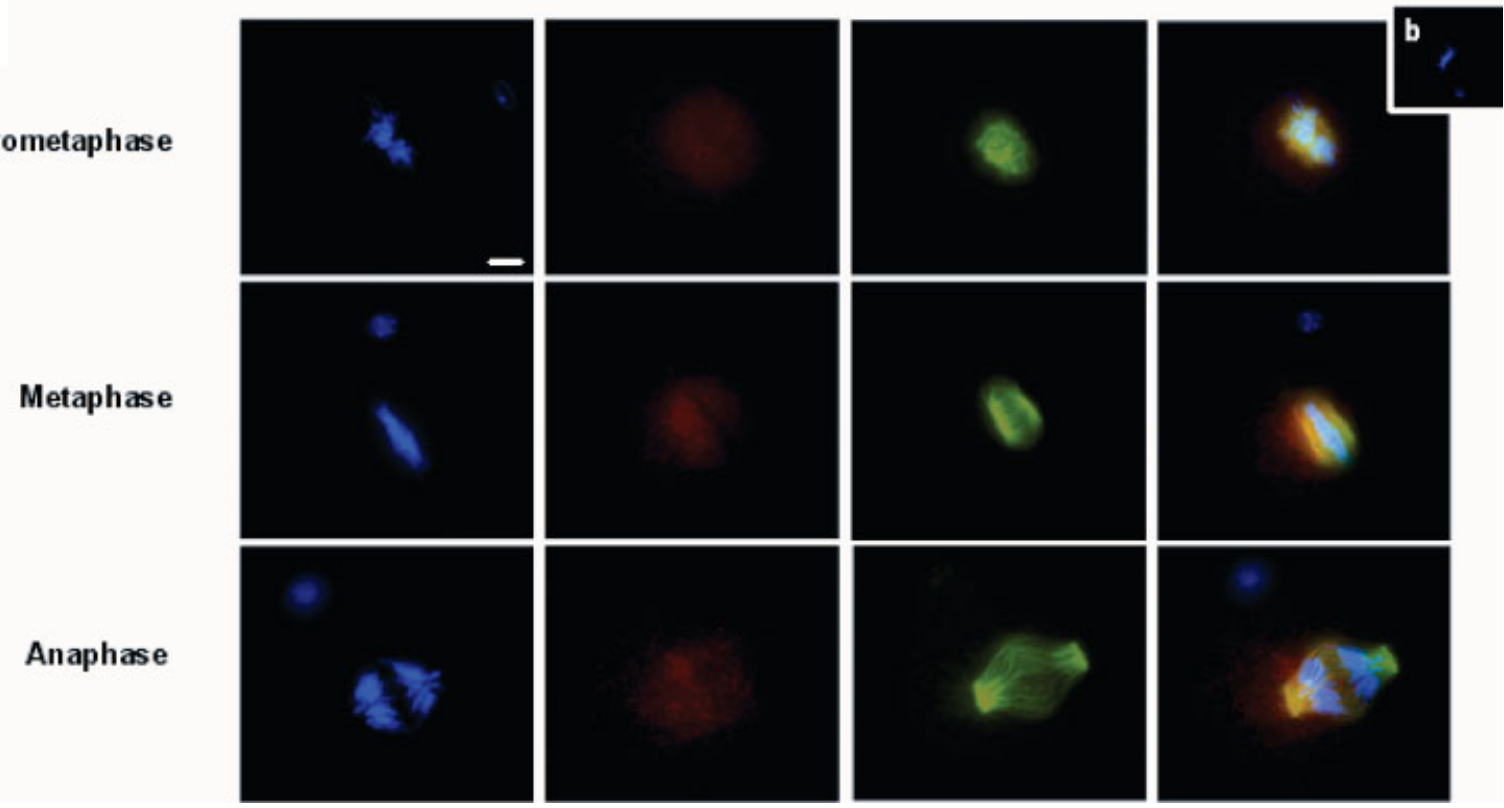

Fig. 2. GSK-3 associates with the mitotic spindle apparatus during the first cleavage event. A: Immunostaining of embryo during the first mitotic metaphase showed accumulation of GSK- $3 \alpha / \beta$ protein (red) around the condensed chromatin (blue) of the metaphase plate. Immunostaining control (NIMS) showed no reactivity (a; insert). B: Representative micrographs of GSK- $3 \alpha$ protein distribution in relation

phosphorylated at the serine residue, similar to somatic cell control (Fig. 1B).

Immunocytochemical analysis showed accumulation of GSK-3 $\alpha / \beta$ surrounding metaphase plate during the first embryonic mitosis (Fig. 2A). Co-staining cells for GSK-3 $\alpha$ and $\beta$-tubulin confirmed that GSK-3 co-localized with mitotic spindles as cells entered and progressed through metaphase (Fig. 2B). As cells progressed through anaphase, GSK-3 became more diffusely distributed throughout the cytoplasm (Fig. 2B).

\section{GSK-3 Activity is Critical for Normal Chromatin Segregation and Cytokinesis}

To determine importance of GSK-3 in early embryo mitotic progression, anti-GSK-3 $\alpha / \beta$ antibody was microinjected into the cytoplasm of pronuclear-stage embryos and cleavage events were assessed in 24-hr intervals for $48 \mathrm{hr}$. Microinjection controls were similar to each other in rate of development at 24 and $48 \mathrm{hr}$ of culture (Table 1). Microinjection of anti-GSK-3 antibody significantly compromised development past the twocell stage by $48 \mathrm{hr}$ of culture compared to controls (Table 1). As important, the majority of embryos microinjected with anti-GSK-3 that underwent the first

to the spindle apparatus during the first mitotic prometaphase, metaphase, and anaphase. GSK- $3 \alpha$ closely associates with the spindle microtubules (depicted by polymerized $\beta$-tubulin (green)) during prometaphase and metaphase, and then becomes more diffuse throughout the cytoplasm during anaphase. Immunostaining control (NIRS) showed no reactivity (b; insert). Bar, $10 \mu \mathrm{m}$.

mitotic division remained arrested at the two-cell stage by $72 \mathrm{hr}$, without exhibiting cellular fragmentation or degeneration (data not shown).

To ascertain if pharmacological inhibition of GSK-3 activity affected early mitotic progression, in vivogenerated zygotes were collected at the pronuclear stage, cultured for $72 \mathrm{hr}$ in KSOM alone or with 1,10 ,

TABLE 1. Effects of Anti-GSK-3 $\alpha / \beta$ Antibody Microinjection on Development of Embryos Cultured for $48 \mathrm{hr}$ (Post-Treatment)

\begin{tabular}{lccc}
\hline Treatment & $\mathrm{N}$ & $\begin{array}{c}\text { Development } \\
\text { at } 24 \mathrm{hr} \\
\text { two-cell }(\%)\end{array}$ & $\begin{array}{c}\text { Development } \\
\text { at } 48 \mathrm{hr} \\
\text { four-cell }(\%)\end{array}$ \\
\hline $\begin{array}{l}\text { PBS alone } \\
\text { Mouse IgG }\end{array}$ & 70 & 85 & 79 \\
$\begin{array}{l}\text { Antibody diluent } \\
\text { alone }\end{array}$ & 97 & 68 & 60 \\
GSK-3 antibody & 110 & 77 & 86 \\
\hline
\end{tabular}

$\mathrm{N}$, number of embryos assessed in each treatment group.

${ }^{a}$ Vehicle control for mouse IgG microinjection.

${ }^{b}$ Vehicle control for GSK-3 antibody microinjection.

${ }^{c}$ Value significantly different from controls. 
or $20 \mathrm{mM} \mathrm{LiCl}$, and examined microscopically in $24-\mathrm{hr}$ intervals. Similar to anti-GSK-3 antibody microinjection, embryo development was significantly compromised in a dose-dependent manner by $48 \mathrm{hr}$ of culture with significantly fewer embryos developing beyond the two-cell stage in 10 and $20 \mathrm{mM} \mathrm{LiCl}$ (Fig. 3A). Interestingly, embryos cultured in $\mathrm{LiCl}$ for $72 \mathrm{hr}$ that failed to cleave past the two-cell stage had blastomeres that appeared viable and did not exhibit fragmentation. These results were comparable to those observed following antibody neutralization.

LiCl inhibits both GSK-3 and IMPase (Berridge et al., 1989; Klein and Melton, 1996). To ascertain that repression of development by $\mathrm{LiCl}$ was not due to inhibition of IMPase activity, one-cell embryos were cultured for $72 \mathrm{hr}$ in KSOM alone, $20 \mathrm{mM} \mathrm{LiCl}, 20 \mathrm{mM}$ $\mathrm{KCl}$ (molarity control for LiCl), or $20 \mu \mathrm{M} \mathrm{L}-690,330$ (specific IMPase inhibitor). At $48 \mathrm{hr}$ of culture, only zygotes cultured in LiCl had significantly compromised development beyond the two-cell stage compared to KSOM, KCl, and L-690, 330 (Fig. 3B). To establish if embryos could regain mitotic potential after removal from GSK-3 inhibition, one-cell embryos were cultured for up to $30 \mathrm{hr}$ in $\mathrm{KSOM}, 20 \mathrm{mM} \mathrm{LiCl}$, or $20 \mathrm{mM} \mathrm{KCl}$, then washed and transferred to KSOM alone for up to $48 \mathrm{hr}$ total culture. Embryos cultured in $\mathrm{LiCl}$ for $24 \mathrm{hr}$

A

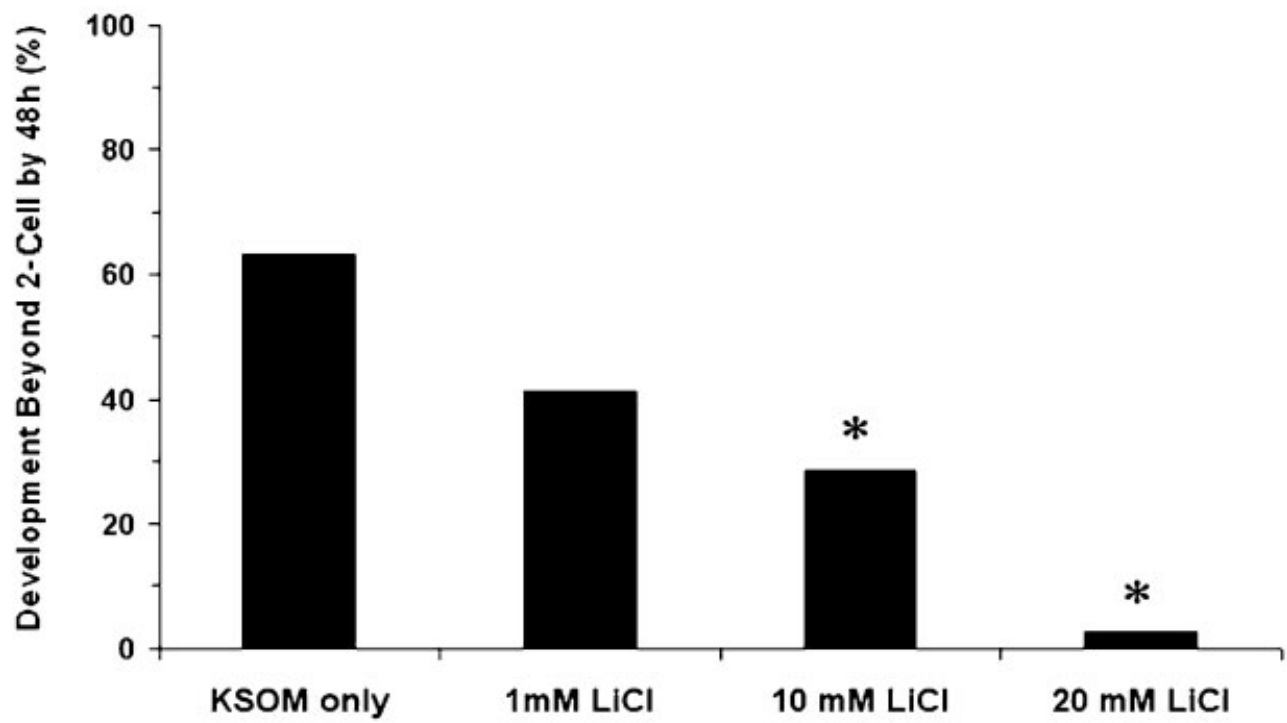

B

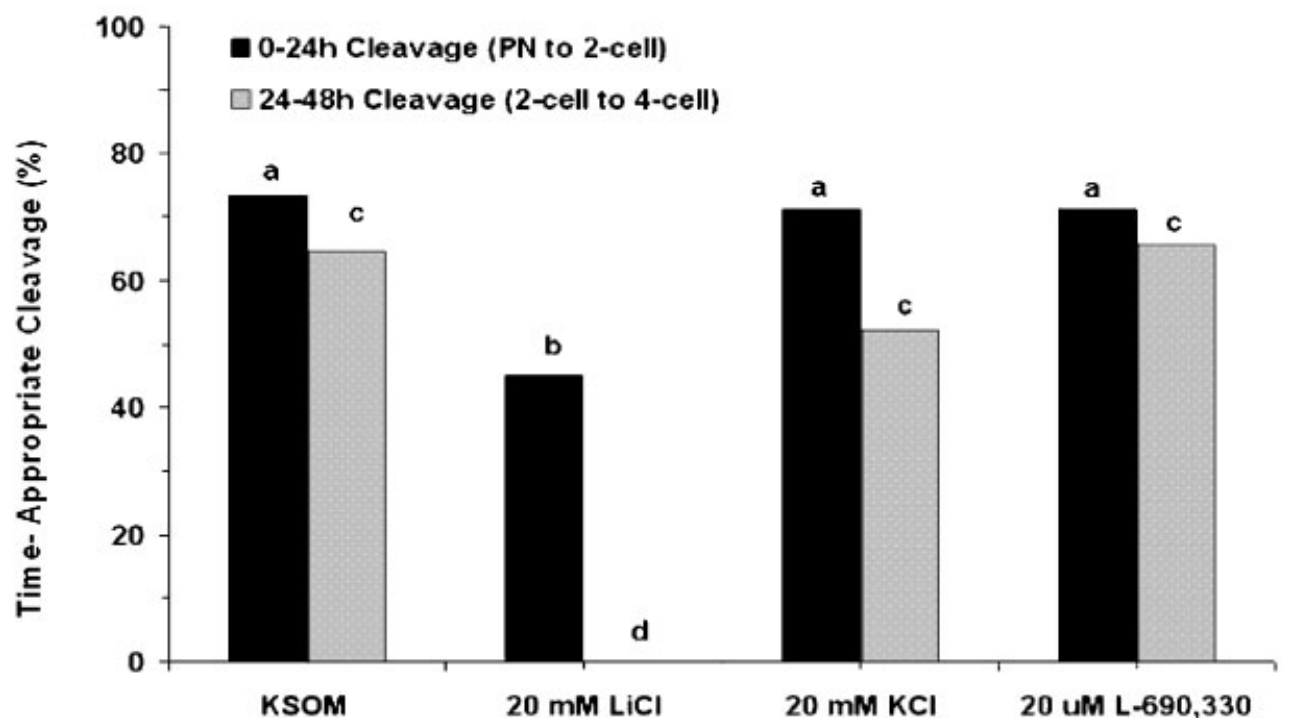

Fig. 3. Pharmacological inhibition of GSK-3 via lithium chloride (LiCl) blocks embryonic development past the two-cell stage. A: LiCl compromised embryo development in a dose-dependent manner. Percentage of zygotes cultured for $48 \mathrm{hr}$ in either control media, or in the presence of $1 \mathrm{mM}, 10 \mathrm{mM}$, or $20 \mathrm{mM} \mathrm{LiCl}$, with normal cleavage past the two-cell stage. ( $\mathrm{N}=76-112$ embryos/treatment). Columns with asterisks indicate significantly different from control $(P<0.001)$.
B: Inhibition of GSK-3, but not IMPase, activity during early embryo development blocked development at the two-cell stage. Percentage of time-appropriate cleavage after zygotes were cultured for 24 or $48 \mathrm{hr}$ in either control media (KSOM), $20 \mathrm{mM} \mathrm{LiCl,} 20 \mathrm{mM} \mathrm{KCl}$, or $20 \mu \mathrm{M} \mathrm{L}-690$, 330. ( $\mathrm{N}=85-102$ embryos/treatment). $\mathbf{a}, \mathbf{b} ; \mathbf{c}, \mathbf{d}$ : Columns with similar colors and different letters are significantly different. 


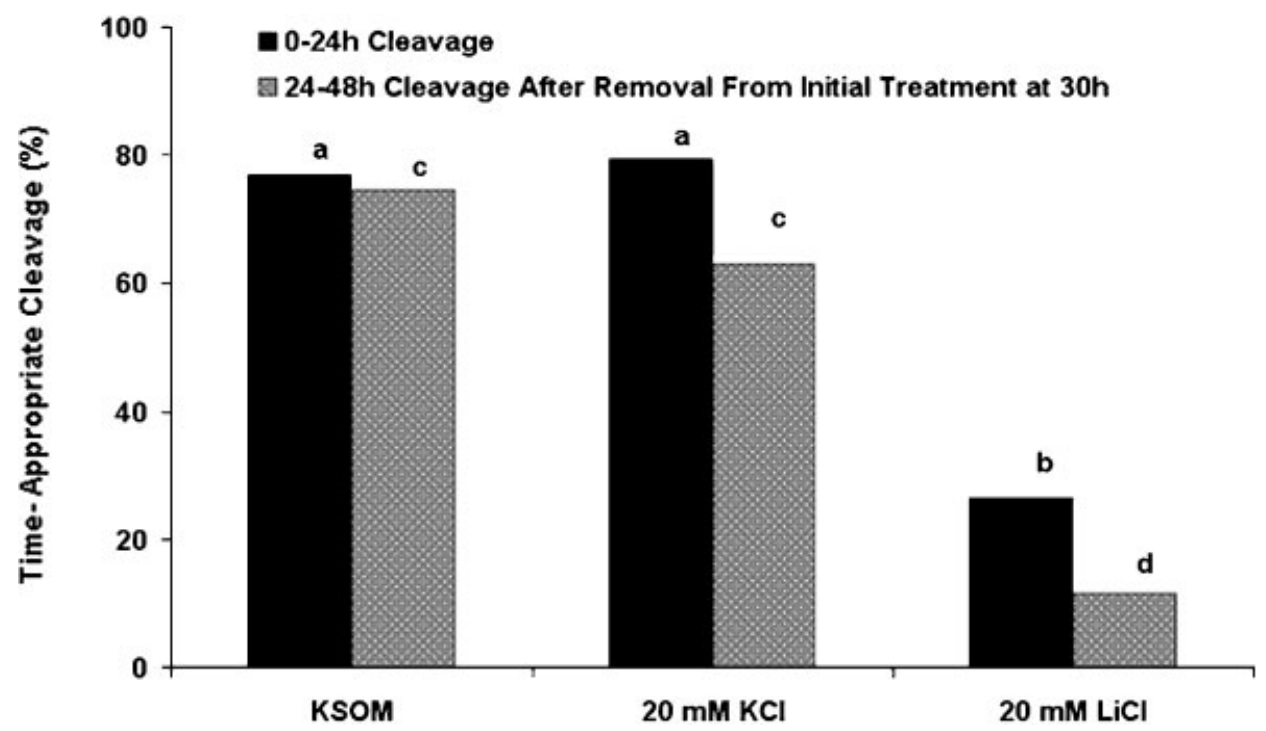

Fig. 4. Removal from GSK-3 inhibitory media after $30 \mathrm{hr}$ of culture did not result in resumption of mitotic potential. Percentage of time-dependent cleavage measured after $24 \mathrm{hr}$ of total culture in either control media (KSOM), $20 \mathrm{mM} \mathrm{LiCl}$, or $20 \mathrm{mM} \mathrm{KCl}$. At $30 \mathrm{hr}$ of culture, embryos in all treatment groups were washed and cultured in control media. Percentage of time-appropriate cleavage after removal from inhibitor media measured at $48 \mathrm{hr}$ of total culture $(\mathrm{N}=82-92$ embryos/treatment). a,b; $\mathbf{c}, \mathbf{d}$ : Columns with similar colors and different letters are significantly different.

had significantly reduced cleavage rates compared to those cultured in KSOM or KCl (Fig. 4). By $48 \mathrm{hr}, \mathrm{LiCl}$ treated embryos did not undergo significant new cleavage in relation to those cultured in KSOM and $\mathrm{KCl}$ treated embryos, suggesting an irreversible disruption of mitotic cell cycle progression.

To validate that observed blocks on mitotic progression were due to inhibition of GSK-3 and not inhibition of CDK activity, zygotes were cultured in presence of either $20 \mathrm{mM} \mathrm{LiCl}, 20 \mu \mathrm{M}$ alsterpaullone, or $80 \mu \mathrm{M}$ roscovitine. Administration of $20 \mu \mathrm{M}$ alsterpaullone has been shown to prevent in vivo phosphorylation of tau epitopes phosphorylated by GSK-3 without affecting phosphorylation of tau epitopes phosphorylated by CDK5 (Leost et al., 2000; Tatebayashi et al., 2004). By $48 \mathrm{hr}$, there was a marked developmental difference between embryos cultured in either $\mathrm{LiCl}$ or alsterpaullone, which failed to cleave past the two-cell stage, and embryos cultured in roscovitine, in which $21 \%$ of zygotes developed to the four-cell stage (Table 2). As important, there was a greater rate of degeneration in the roscovitine-treated embryos at both 24 and $48 \mathrm{hr}$ of culture, compared to all other treatment groups (Table 2). Thus, pharmacological inhibition of GSK-3 activity via $\mathrm{LiCl}$ and/or alsterpaullone mimics the developmental defect following immunoneutralization of endogenous GSK-3 protein prior to the first embryonic cell division.

To further characterize the nature of this arrested development, we examined GSK-3-inhibited embryos for both nuclear and cytoplasmic anomalies. Zygotes were cultured for $24 \mathrm{hr}$ in $\mathrm{KSOM}$ or $20 \mathrm{mM} \mathrm{LiCl}$, and microscopically examined at $3 \mathrm{hr}$-intervals. $\mathrm{LiCl}$ treatment did not significantly influence timing of pronuclear migration, however, timing of pronuclear membrane breakdown and mitosis initiation was significantly different between treatments (Table 3). By $24 \mathrm{hr}$ of

TABLE 2. Pharmacological Inhibition of GSK-3 via Alsterpaullone Blocks Embryo Development at the two-Cell Stage in a CDK-Independent Manner

\begin{tabular}{|c|c|c|c|c|c|}
\hline Treatment & $\mathrm{N}$ & $\begin{array}{l}\text { Development at } \\
24 \mathrm{hr} \geq \mathrm{two} \text {-cell } \\
(\%)\end{array}$ & $\begin{array}{l}\text { Development at } \\
48 \mathrm{hr} \geq \text { four-cell } \\
(\%)\end{array}$ & $\begin{array}{c}\text { Degeneration } \\
\text { at } 24 \mathrm{hr}(\%)\end{array}$ & $\begin{array}{c}\text { Degeneration } \\
\text { at } 48 \mathrm{hr}(\%)\end{array}$ \\
\hline $\mathrm{KSOM}^{\mathrm{a}}$ & 41 & 88 & 76 & 0 & 10 \\
\hline 20 mM LiCl & 45 & $42^{\mathrm{d}}$ & $0^{d}$ & 9 & 9 \\
\hline DMSO alone $\mathrm{e}^{\mathrm{b}}$ & 45 & 92 & 89 & 9 & 9 \\
\hline $20 \mu \mathrm{M}$ alsterpaullone & 44 & 80 & $0^{d}$ & 9 & 18 \\
\hline DMSO alone $\mathrm{e}^{\mathrm{c}}$ & 32 & 83 & 81 & 7 & 12 \\
\hline $80 \mu \mathrm{M}$ roscovitine & 40 & $56^{\mathrm{d}}$ & $21^{d}$ & 29 & 33 \\
\hline
\end{tabular}

$\mathrm{N}$, number of embryos assessed in each treatment group.

${ }^{\mathrm{a}}$ Control for $20 \mathrm{mM} \mathrm{LiCl}$.

${ }^{b}$ Vehicle control for $20 \mu \mathrm{M}$ alsterpaullone.

${ }^{c}$ Vehicle control for $80 \mu \mathrm{M}$ roscovitine.

${ }^{\mathrm{d}}$ Values significantly different from control $[P<0.01]$. 
TABLE 3. Inhibition of GSK-3 Activity Disrupted Normal Karyokinesis and Cytokinesis During the First Mitotic Division

\begin{tabular}{llcc}
\hline & & \multicolumn{2}{c}{ Treatment } \\
\cline { 3 - 4 } Time (post-hCG) & \multicolumn{1}{c}{ Developmental event } & KSOM (\%Total) & LiCl (\%Total) \\
\hline & & $\mathrm{N}=38$ & $\mathrm{~N}=39$ \\
$28 \mathrm{hr}$ & Pronuclear migration & 86 & 78 \\
$35 \mathrm{hr}$ & Pronuclear membrane breakdown & 43 & $19^{*}$ \\
$48 \mathrm{hr}$ & Complete karyokinesis & 95 & $28^{*}$ \\
$48 \mathrm{hr}$ & Complete cytokinesis & 95 & $40^{*}$ \\
\hline
\end{tabular}

$\mathrm{N}$, number of embryos assessed in each treatment group.

Asterisk (*) denotes significant difference in time of developmental event between LiCl-treated group and control (KSOM).

culture (48 hr post-hCG), LiCl treatment significantly compromised both nuclear formation and cytokinesis compared to control (Table 3).

Nuclear staining of embryos after $24 \mathrm{hr}$ of culture in either KSOM, $20 \mathrm{mM} \mathrm{KCl,} 20 \mathrm{mM} \mathrm{LiCl}$, or $20 \mu \mathrm{M}$ alsterpaullone showed abnormal chromatin segregation patterns in GSK-3 inhibited embryos compared to controls (Fig. 5). Control embryos (KSOM, KCl) developed into two distinct blastomeres with properly segregated daughter nuclei. GSK-3 inhibition ( $\mathrm{LiCl}$, alsterpaullone) showed abnormal chromatin segregation patterns, evidenced by incomplete karyokinesis and micronuclei formation. As important, both timing and completion of cytokinesis were also compromised in conjunction with this incomplete karyokinesis in GSK-3 inhibited embryos (Table 1, Fig. 5).

\section{DISCUSSION}

In the present study we have shown that GSK-3 protein is expressed during mammalian preimplantation embryo development in a temporal, isoform-specific manner. GSK-3 is a highly conserved serine/threonine protein kinase that consists of two closely related isoforms, $\alpha$ and $\beta$ (Woodgett, 1990). Despite displaying similar biochemical properties to the $\alpha$ isoform, the GSK-3 $\beta$ isoform has been more thoroughly investigated in mammalian somatic cell systems because it more closely resembles its Drosophila homologue, $Z w 3$, supporting the assumption that only the $\beta$ isoform is involved in Wnt signaling in mammalian cells (Hoeflich et al., 2000). Our data showed a differential expression of GSK- $3 \alpha$ to GSK- $3 \beta$ throughout oocyte maturation and

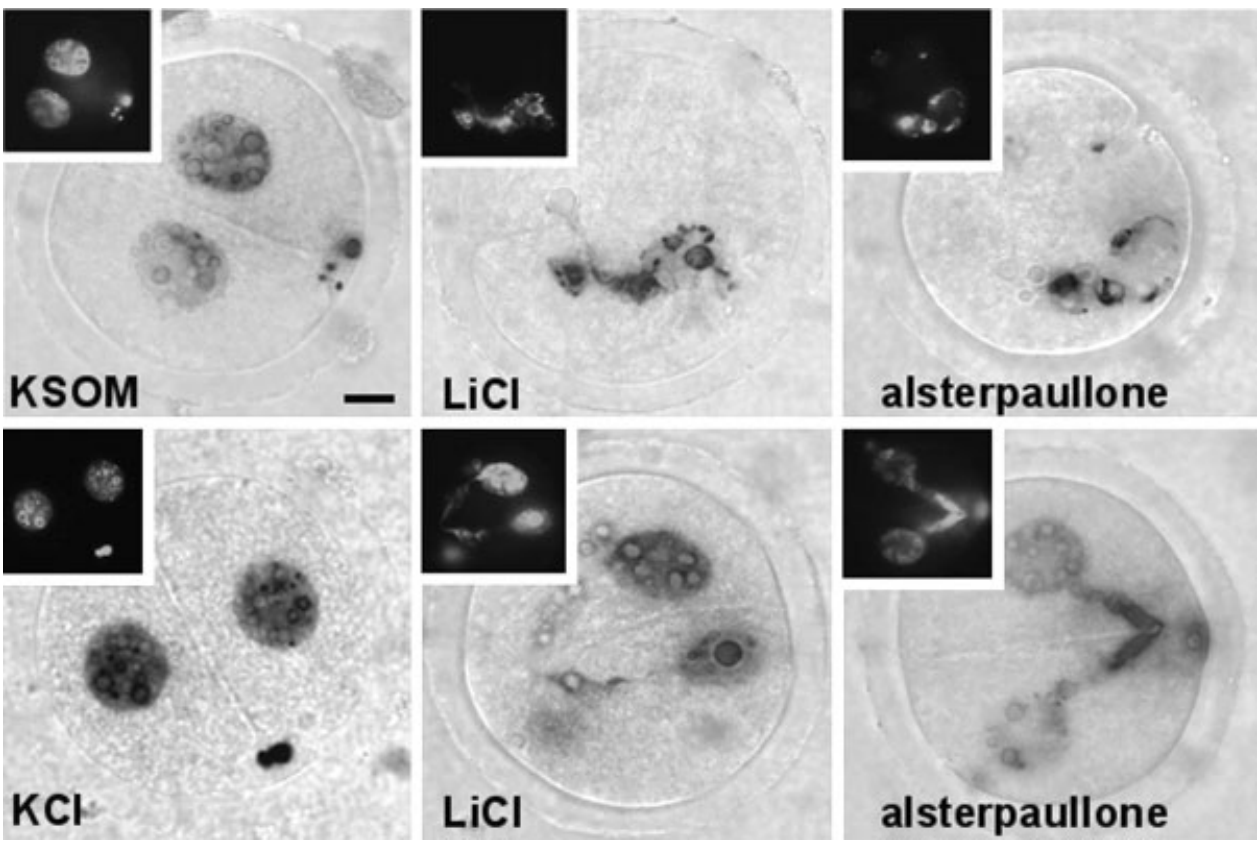

Fig. 5. Inhibition of GSK-3 activity resulted in chromatin segregation abnormalities. Representative micrographs of embryos cultured for $24 \mathrm{hr}$ in either KSOM, $20 \mathrm{mM} \mathrm{KCl}, 20 \mathrm{mM} \mathrm{LiCl}$, or $20 \mu \mathrm{M}$ alsterpaullone, then fixed and stained with Hoechst 33342 (white in inset; dark grey in brightfield phase contrast overlays) to visualize the chromatin segregation patterns. Bar, $10 \mu \mathrm{m}$. 


\section{N. ACEVEDO ET AL.}

early embryonic development. Of greatest interest was the predominant expression of GSK-3 $\alpha$ in early dividing embryos (two- and four-cell stage), and the shift to an increased expression of GSK-3 $\beta$ by the blastocyst stage. This would indicate that GSK-3 $\beta$ is either a gene that is transcribed and translated in response to ZGA and/or that GSK-3 $\beta$ may be an important kinase in preimplantation embryonic cell fate determination as embryonic blastomeres make the transition to differentiated cell populations. It will be of interest in future studies to determine if cells of the trophoblast, or inner cell mass, preferentially express GSK-3 $\beta$.

Our results indicate a temporal regulation of GSK-3 activity during oocyte maturation and early embryonic development via differential phosphorylation of GSK-3 serine (S21 of $\alpha / \mathrm{S} 9$ of $\beta$ ) and tyrosine (Y279 of $\alpha / \mathrm{Y} 216$ of $\beta$ ) residues. Activation of the PI3K signaling pathway mediates GSK-3 activity through phosphorylation and activation of $\mathrm{PKB}$, which, in turn, phosphorylates and inactivates GSK-3 on an N-terminal serine (S21/S9) residue (Cohen and Frame, 2001). The induced inhibition of GSK-3 activity leads to dephosphorylation of GSK-3 substrates via protein phosphatases (Cohen and Frame, 2001). In resting mammalian cells, the tyrosine (Y279/Y216) residues of GSK-3 $\alpha / \beta$ are constitutively phosphorylated, promoting kinase activation. Our results indicate that during oocyte maturation and early embryonic development, tyrosine (Y279/Y216) phosphorylation patterns mimic overall protein expression patterns for each isoform. However, serine (S21/S9) phosphorylation patterns were distinctly different from protein expression during preimplantation embryo development. Although $\alpha$ was the predominant isoform expressed during early embryonic divisions, both $\alpha$ and $\beta$ were phosphorylated on the serine residue during these stages. Interestingly, at the blastocyst stage only the $\beta$ isoform exhibited serine phosphorylation, a pattern similar to that observed in the somatic cell control (mouse brain). These phosphorylation patterns indicate differential regulation of GSK-3 activity between early and late embryonic development via different isoforms.

Immunoneutralization of endogenous GSK-3 protein function following fertilization but prior to the first mitotic metaphase resulted in a distinct block on development past the two-cell stage. A limitation to the immunoneutralization approach is inability to test reversibility of inhibitory effects. To address this issue, we employed a combined pharmacological approach to investigate early developmental processes regulated by GSK-3 in mouse embryos. In assessing the appropriate physiological targets of any pharmacological inhibitor, it is important to consider that selective substrate inhibition by a pharmacological agent in a cell-free extract does not necessarily translate to substrate inhibition in vivo. In cell-free extracts, alsterpaullone potently inhibits GSK-3 and CDK5 activity at IC $_{50}$ values of 0.004 and $0.04 \mu \mathrm{M}$, respectively (Leost et al., 2000). In cell culture, however, $20 \mu \mathrm{M}$ alsterpaullone more potently inhibits activity of GSK-3 than CDK5, at a concentration much higher than the $\mathrm{IC}_{50}$ for either kinase (Leost et al.,
2000; Tatebayashi et al., 2004). The combined use of alsterpaullone and $\mathrm{LiCl}$ as pharmacological inhibitors of GSK-3 is validated by reports that alsterpaullone potently and selectively inhibits GSK-3 and CDK1/2/5 in vitro, whereas $\mathrm{LiCl}$ potently inhibits GSK-3 with no known inhibitory effect on CDK activity (Klein and Melton, 1996; Davies et al., 2000; Leost et al., 2000; Phiel and Klein, 2001). In our studies, embryos cultured in the selective CDK inhibitor, roscovitine, had significantly compromised development at the two-cell stage and beyond, and displayed an increased rate of degeneration and fragmentation, compared to controls. In comparison, embryos cultured in either $\mathrm{LiCl}$ or alsterpaullone failed to cleave past the first mitotic division without exhibiting cellular fragmentation, and resulted in chromatin and cytoskeletal abnormalities. Thus, within this experimental model system, we have demonstrated a common developmental consequence of GSK-3 inhibitors $\mathrm{LiCl}$ and alsterpaullone, yet a very different developmental influence of the CDK inhibitor, roscovitine.

Despite a comparable block on development past the two-cell stage, $\mathrm{LiCl}$ and alsterpaullone-treated zygotes did differ in the percent that underwent the first mitotic division (Table 2). The cause for this discrepancy is currently unknown. One explanation may be that the two pharmacological inhibitors exhibit different potencies that relate to their mode of interaction with GSK-3 (Leost et al., 2000; Ryves and Harwood, 2001; Song et al., 2002; Bertrand et al., 2003; Zhang et al., 2003).

We have shown that both GSK-3-neutralizing antibody microinjection and pharmacological inhibition irreversibly compromised early preimplantation embryo development through a developmental block characterized by abnormal chromatin segregation and incomplete cytokinesis. This does not appear to be a consequence of induction of an apoptotic or necrotic response, because this developmental block is not followed by embryo fragmentation, degeneration, or death. Irreversible disruption of development past the two-cell stage suggested that the influence of GSK-3 inhibition results in an irremediable structural problem. This was investigated by quantifying nuclear and cytoplasmic transitions during the first mitotic division and nuclear and cytoplasmic structure of the arrested embryos. Results indicate that inhibition of GSK-3 activity caused uncoupling of cytokinesis from completion of karyokinesis, and compromised completion of karyokinesis.

Equal separation of the genome duplicated during mitosis depends on proper formation and function of mitotic spindles (Tournebize et al., 1997; Nasmyth et al., 2001). Several studies have implicated GSK-3 in regulation of mitotic microtubule dynamics that produces a competent spindle apparatus for successful chromosomal segregation (Lovestone et al., 1996; Doxsey, 2001; Wakefield et al., 2003). Wakefield and colleagues (2003) showed that GSK-3 protein associates with microtubules along the length of the spindle. In the present study, GSK-3 was also found to co-localize with 
the first embryonic mitotic spindle. This intracellular location, in conjunction with microscopic observations of incomplete chromatin segregation at the first embryonic mitotic division following GSK-3 inhibition, supports a role for GSK-3 in proper spindle function and/or completion of chromatin separation. From a structural and developmental focus one can appreciate that this incomplete karyokinesis, in association with a structurally and/or functionally abnormal spindle, may physically hinder the completion of cytokinesis observed in this study.

In conclusion, we have demonstrated that GSK-3 activity is critical for proper and timely progression of mammalian zygotes through the first mitotic division, in that inhibition of GSK-3 activity during the first cell cycle leads to abnormal chromatin segregation and failure to develop past the two-cell stage. As important, we found that GSK-3 plays a role in mediating timing and completion of cytokinesis. Further investigation is required to determine if GSK-3 influences proper chromatin segregation during the early cleavage events of the preimplantation embryo via regulation of spindle function, chromatin remodeling proteins, or GSK-3 phosphoprotein substrates that translate the GSK-3 signal necessary for completion of the first embryonic mitotic division.

\section{ACKNOWLEDGMENTS}

The authors would like to thank Drs. Carrie CosolaSmith and Thomas Pool for critical review of this manuscript. We are also grateful to Dr. Thomas Saunders at the Transgenic Animal Core Facility at the University of Michigan for technical assistance with the zygote microinjection studies.

\section{REFERENCES}

Alvarez B, Garrido E, Garcia-Sanz JA, Carrera AC. 2003. Phosphoinositide 3-kinase activation regulates cell division time by coordinated control of cell mass and cell cycle progression rate. J Biol Chem 278:26466-26473.

Bain J, McLauchlan H, Elliott M, Cohen P. 2003. The specificities of protein kinase inhibitors: An update. Biochem J 371:199-204.

Battaglia DE, Goodwin P, Klein NA, Soules MR. 1996. Influence of maternal age on meiotic spindle assembly in oocytes from naturally cycling women. Hum Reprod 11:2217-2222.

Berridge MJ, Downes CP, Hanley MR. 1989. Neural and developmental actions of lithium: A unifying hypothesis. Cell 59:411-419.

Bertrand JA, Thieffine S, Vulpetti A, Cristiani C, Valsasina B, Knapp S, Kalisz HM, Flocco M. 2003. Structural characterization of the GSK3beta active site using selective and non-selective ATP-mimetic inhibitors. J Mol Biol 333:393-407.

Cho JH, Johnson GV. 2003. Glycogen synthase kinase 3beta phosphorylates tau at both primed and unprimed sites. Differential impact on microtubule binding. J Biol Chem 278:187-193.

Ciemerych MA. 1995. Chromatin condensation activity and cortical activity during the first three cell cycles of a mouse embryo. Mol Reprod Dev 41:416-424.

Ciemerych MA, Czolowska R. 1993. Differential chromatin condensation of female and male pronuclei in mouse zygotes. Mol Reprod Dev 34:73-80.

Cohen P, Frame S. 2001. The renaissance of GSK3. Nat Rev Mol Cell Biol 2:769-776.

Collas P, Le Guellec K, Tasken K. 1999. The A-kinase-anchoring protein AKAP95 is a multivalent protein with a key role in chromatin condensation at mitosis. J Cell Biol 147:1167-1180.
Corson DW, Fein A. 1983. Quantitative pressure injection of picoliter volumes into Limulus ventral photoreceptors. Biophys J 44:299304.

Davidson EH, Cameron RA, Ransick A. 1998. Specification of cell fate in the sea urchin embryo: Summary and some proposed mechanisms. Development 125:3269-3290.

Davies SP, Reddy H, Caivano M, Cohen P. 2000. Specificity and mechanism of action of some commonly used protein kinase inhibitors. Biochem J 351:95-105.

Delaval B, Ferrand A, Conte N, Larroque C, Hernandez-Verdun D, Prigent C, Birnbaum D. 2004. Aurora B -TACC1 protein complex in cytokinesis. Oncogene 23:4516-4522.

do Carmo Avides M, Tavares A, Glover DM. 2001. Polo kinase and Asp are needed to promote the mitotic organizing activity of centrosomes. Nat Cell Biol 3:421-424.

Dominguez I, Itoh K, Sokol SY. 1995. Role of glycogen synthase kinase 3 beta as a negative regulator of dorsoventral axis formation in Xenopus embryos. Proc Natl Acad Sci USA 92:8498-8502.

Doxsey S. 2001. Re-evaluating centrosome function. Nat Rev Mol Cell Biol 2:688-698.

Embi N, Rylatt DB, Cohen P. 1980. Glycogen synthase kinase-3 from rabbit skeletal muscle. Separation from cyclic-AMP-dependent protein kinase and phosphorylase kinase. Eur J Biochem 107:519_ 527.

Emily-Fenouil F, Ghiglione C, Lhomond G, Lepage T, Gache C. 1998 GSK3beta/shaggy mediates patterning along the animal-vegetal axis of the sea urchin embryo. Development 125:2489-2498.

Gebauer F, Richter JD. 1997. Synthesis and function of Mos: The control switch of vertebrate oocyte meiosis. Bioessays 19:23-28.

Generoso WM, Katoh M, Cain KT, Hughes LA, Foxworth LB, Mitchell TJ, Bishop JB. 1989. Chromosome malsegregation and embryonic lethality induced by treatment of normally ovulated mouse oocytes with nocodazole. Mutat Res 210:313-322.

Guadagno TM, Ferrell JE, Jr. 1998. Requirement for MAPK activation for normal mitotic progression in Xenopus egg extracts. Science 282:1312-1315.

Hannak E, Kirkham M, Hyman AA, Oegema K. 2001. Aurora-A kinase is required for centrosome maturation in Caenorhabditis elegans. J Cell Biol 155:1109-1116.

Haraguchi S, Naito K, Sato E. 1998. MAP kinase cascade, but not ERKs, activated during early cleavage of mouse embryos. Mol Reprod Dev 51:148-155.

Hedgepeth CM, Conrad LJ, Zhang J, Huang HC, Lee VM, Klein PS. 1997. Activation of the Wnt signaling pathway: A molecular mechanism for lithium action. Dev Biol 185:82-91.

Hedgepeth CM, Deardorff MA, Klein PS. 1999a. Xenopus axin interacts with glycogen synthase kinase-3 beta and is expressed in the anterior midbrain. Mech Dev 80:147-151.

Hedgepeth CM, Deardorff MA, Rankin K, Klein PS. 1999b. Regulation of glycogen synthase kinase 3beta and downstream Wnt signaling by axin. Mol Cell Biol 19:7147-7157.

Hoeflich KP, Luo J, Rubie EA, Tsao MS, Jin O, Woodgett JR. 2000 Requirement for glycogen synthase kinase-3beta in cell survival and NF-kappaB activation. Nature 406:86-90.

Horne MM, Guadagno TM. 2003. A requirement for MAP kinase in the assembly and maintenance of the mitotic spindle. J Cell Biol 161: 1021-1028.

Inoue S. 1981. Cell division and the mitotic spindle. J Cell Biol 91:131s$147 \mathrm{~s}$.

Josefsberg LB, Galiani D, Lazar S, Kaufman O, Seger R, Dekel N. 2003 Maturation-promoting factor governs mitogen-activated protein kinase activation and interphase suppression during meiosis of rat oocytes. Biol Reprod 68:1282-1290.

Kaufman MH. 1973. Timing of the first cleavage division of haploid mouse eggs, and the duration of its component stages. J Cell Sci 13: 553-566.

Klein PS, Melton DA. 1996. A molecular mechanism for the effect of lithium on development. Proc Natl Acad Sci USA 93:8455-8459.

Lawitts JA, Biggers JD. 1993. Culture of preimplantation embryos. Methods Enzymol 225:153-164.

Leost M, Schultz C, Link A, Wu YZ, Biernat J, Mandelkow EM, Bibb JA, Snyder GL, Greengard P, Zaharevitz DW, Gussio R, Senderowicz AM, Sausville EA, Kunick C, Meijer L. 2000. Paullones are potent 


\section{Molecular Reproduction and Development. DOI 10.1002/mrd}

\section{N. ACEVEDO ET AL.}

inhibitors of glycogen synthase kinase-3beta and cyclin-dependent kinase 5/p25. Eur J Biochem 267:5983-5994.

Liu Y, Obata K, Yamanaka H, Dai Y, Fukuoka T, Tokunaga A, Noguchi K. 2004. Activation of extracellular signal-regulated protein kinase in dorsal horn neurons in the rat neuropathic intermittent claudication model. Pain 109:64-72.

Loberg RD, Vesely E, Brosius FC, III. 2002. Enhanced glycogen synthase kinase-3beta activity mediates hypoxia-induced apoptosis of vascular smooth muscle cells and is prevented by glucose transport and metabolism. J Biol Chem 277:41667-41673.

Lovestone S, Hartley CL, Pearce J, Anderton BH. 1996. Phosphorylation of tau by glycogen synthase kinase-3 beta in intact mammalian cells: The effects on the organization and stability of microtubules. Neuroscience 73:1145-1157.

Lovestone S, Davis DR, Webster MT, Kaech S, Brion JP, Matus A, Anderton BH. 1999. Lithium reduces tau phosphorylation: Effects in living cells and in neurons at therapeutic concentrations. Biol Psychiatry 45:995-1003.

Lu Q, Dunn RL, Angeles R, Smith GD. 2002. Regulation of spindle formation by active mitogen-activated protein kinase and protein phosphatase 2A during mouse oocyte meiosis. Biol Reprod 66:29-37.

Masui Y, Markert CL. 1971. Cytoplasmic control of nuclear behavior during meiotic maturation of frog oocytes. J Exp Zool 177:129-145.

Nasmyth K, Peters JM, Uhlmann F. 2001. Splitting the chromosome: Cutting the ties that bind sister chromatids. Novartis Found Symp 237:113-133; discussion 133-8, 158-163.

Ossipova O, Bardeesy N, DePinho RA, Green JB. 2003. LKB1 (XEEK1) regulates Wht signalling in vertebrate development. Nat Cell Biol 5:889-894.

Phiel CJ, Klein PS. 2001. Molecular targets of lithium action. Annu Rev Pharmacol Toxicol 41:789-813.

Pierce SB, Kimelman D. 1995. Regulation of Spemann organizer formation by the intracellular kinase Xgsk-3. Development 121:755-765.

Roberts EC, Shapiro PS, Nahreini TS, Pages G, Pouyssegur J, Ahn NG. 2002. Distinct cell cycle timing requirements for extracellular signalregulated kinase and phosphoinositide 3-kinase signaling pathways in somatic cell mitosis. Mol Cell Biol 22:7226-7241.

Robinson MJ, Cobb MH. 1997. Mitogen-activated protein kinase pathways. Curr Opin Cell Biol 9:180-186.

Ryves WJ, Harwood AJ. 2001. Lithium inhibits glycogen synthase kinase-3 by competition for magnesium. Biochem Biophys Res Commun 280:720-725.

Sang H, Lu Z, Li Y, Ru B, Wang W, Chen J. 2001. Phosphorylation of tau by glycogen synthase kinase 3beta in intact mammalian cells influences the stability of microtubules. Neurosci Lett 312:141-144.

Song L, De Sarno P, Jope RS. 2002. Central role of glycogen synthase kinase-3beta in endoplasmic reticulum stress-induced caspase-3 activation. J Biol Chem 277:44701-44708.
Stambolic V, Ruel L, Woodgett JR. 1996. Lithium inhibits glycogen synthase kinase-3 activity and mimics wingless signalling in intact cells. Curr Biol 6:1664-1668.

Sumoy L, Kiefer J, Kimelman D. 1999. Conservation of intracellular Wnt signaling components in dorsal-ventral axis formation in zebrafish. Dev Genes Evol 209:48-58.

Sun F, Betzendahl I, Pacchierotti F, Ranaldi R, Smitz J, Cortvrindt R, Eichenlaub-Ritter U. 2005. Aneuploidy in mouse metaphase II oocytes exposed in vivo and in vitro in preantral follicle culture to nocodazole. Mutagenesis 20:65-75.

Tatebayashi Y, Haque N, Tung YC, Iqbal K, Grundke-Iqbal I. 2004. Role of tau phosphorylation by glycogen synthase kinase-3beta in the regulation of organelle transport. J Cell Sci 117:1653-1663.

Tournebize R, Andersen SS, Verde F, Doree M, Karsenti E, Hyman AA. 1997. Distinct roles of PP1 and PP2A-like phosphatases in control of microtubule dynamics during mitosis. Embo J 16:5537-5549.

Verlhac MH, de Pennart H, Maro B, Cobb MH, Clarke HJ. 1993. MAP kinase becomes stably activated at metaphase and is associated with microtubule-organizing centers during meiotic maturation of mouse oocytes. Dev Biol 158:330-340.

Verlhac MH, Kubiak JZ, Weber M, Geraud G, Colledge WH, Evans MJ, Maro B. 1996. Mos is required for MAP kinase activation and is involved in microtubule organization during meiotic maturation in the mouse. Development 122:815-822.

Vonica A, Weng W, Gumbiner BM, Venuti JM. 2000. TCF is the nuclear effector of the beta-catenin signal that patterns the sea urchin animal-vegetal axis. Dev Biol 217:230-243.

Wakefield JG, Stephens DJ, Tavare JM. 2003. A role for glycogen synthase kinase-3 in mitotic spindle dynamics and chromosome alignment. J Cell Sci 116:637-646.

Wang X, Liu XT, Dunn R, Ohl DA, Smith GD. 2003. Glycogen synthase kinase-3 regulates mouse oocyte homologue segregation. Mol Reprod Dev 64:96-105.

Welsh GI, Proud CG. 1993. Glycogen synthase kinase-3 is rapidly inactivated in response to insulin and phosphorylates eukaryotic initiation factor eIF-2B. Biochem J 294:625-629.

Winston NJ, Maro B. 1995. Calmodulin-dependent protein kinase II is activated transiently in ethanol-stimulated mouse oocytes. Dev Biol 170:350-352.

Woodgett JR. 1990. Molecular cloning and expression of glycogen synthase kinase-3/factor A. Embo J 9:2431-2438.

Yu Y, Xia P, Li S, Yan Y, Tan J. 2002. Determination and synchronisation of G1-phase of the cell cycle in 2- and 4-cell mouse embryos. Zygote 10:245-251.

Zhang F, Phiel CJ, Spece L, Gurvich N, Klein PS. 2003. Inhibitory phosphorylation of glycogen synthase kinase-3 (GSK-3) in response to lithium. Evidence for autoregulation of GSK-3. J Biol Chem 278 $33067-33077$. 